\title{
The Hut at Strathmore - TWAIL for a Culturally Appropriate Teaching of Public International Law in African Law Schools
}

\author{
NcikoWa Nciko Arnold
}

\begin{abstract}
The teaching of Public International Law (PIL) in African law schools is backward. While Article 13 of the International Covenant on Economic, Social and Cultural Rights demands that, for education to be acceptable, it must also be culturally appropriate, the teaching of PIL in our schools is largely only reflective of European westernisation. This study reviews relevant literature in law, sociology, international relations, history and politics, and rely on surveys on PIL syllabi in select leading African law schools to attempt to make this violation more explicit. As a recommendation of a possible way forward, the study provides PIL as taught in the Hut at Strathmore Law School. The Hut is an intellectual movement within Strathmore Law School that has tried to contextualise Third World Approaches to International Law (TWAIL) to Africa.
\end{abstract}

Keywords: Coloniality, Critical Race Theory, Culture, Decolonisation, Hut, PIL, Postcoloniality, Triple Heritage Theory, TWAIL

\footnotetext{
The author is a Graduate Assistant at Strathmore Law School and a Regional Representative at the Afronomicslaw Academic Forum. He wishes to acknowledge the Hutians interviewed, Dr Antoinette Kankindi, Mr Arnold Ombasa, Mr Emmanuel Ekiru, Mr Abdullahi Abdirahman, Mr Abdulmalik Sugow, Mr Desmond Tutu, Ms Emma Senge, Ms Gladys Ombati, Ms Stacey Ang'Ina, Ms Winfred Kiberu, Ms Mitchelle Ondili and AMLA 2018 delegates from Francophone and Lusophone countries for their meaningful support and advice in writing this piece. It was indeed the author's great pleasure, honour and privilege to have had this work reviewed by Professors Antony Anghie, James Gathii and Mohsen al Attar, who have made and continue to make the mouvment Third World Approaches to International Law (TWAIL) grow in leaps and bounds. He also wishes to thank in a very special way the editors of the Strathmore Law Review, Professor Babatunde Fagbayibo, and Walimu John Osogo Ambani, Humphrey Sipalla, Allan Mukuki, Melissa Mungai and Lily Mburu for their reviews and for inspiring the perspective that he has taken. His thanks go also to all those took part in the 2020 joint Afronomicslaw and CIL-TRILA Symposium on 'Teaching and Researching International Law - Global Perspectives', where a blog version of this work was presented. Your feedback was taken sportively and constructively.
} 


\section{Table of Contents}

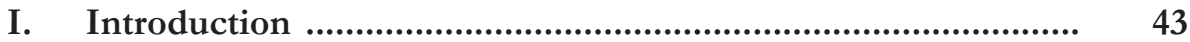

II. Conceptual Framework …........................................................... 45

i. On the meaning of 'culturally appropriate' ............................................... 45

ii. Historical Continuities ........................................................................ 48

III. Surveys on PIL Syllabi in Select Leading African Law Schools 52

i. History ...................................................................................... 54

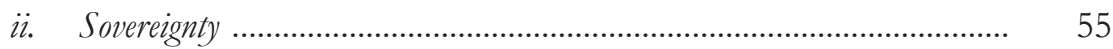

iii. Sources...................................................................................... 57

iv. Treaties........................................................................................ 59

IV. The Hut at Strathmore, Teaching of PIL and TWAIL............ 59

i. The Hut at Strathmore......................................................................... 60

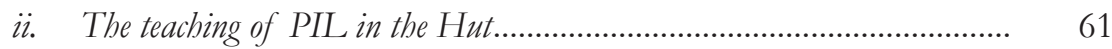

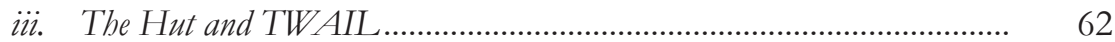

V. Concluding Remarks …......................................................... 66 


\section{Introduction}

'As a third world scholar, the only ethical relationship I can have with Eurocentric international law is one of objection and I choose to articulate this dissent by invoking the teaching of critical international law in these spaces'.

In a larger portion of the seventeenth century, in present-day Angola, there reigned Sousa Nzinga Mbande of Ndongo, queen of the Mbundu people. Although the pages of history, as passed down to us by Europe, credit the Berlin Conference of 1885 for the abolition of slavery in Africa, ${ }^{2}$ already two centuries prior to this Conference, Queen Nzinga was a slavery-abolitionist. She 'waged a fierce and protracted war against the Portuguese and succeeded in recapturing important territories that they used for trafficking captured Africans into slavery. She then declared the territories she had liberated 'free zones', to which any enslaved person could escape and live as a free person'. It is territories similar to these that Micere Githae Mugo has coined 'liberated zones'. These are territories in which freedom fighters proclaim their independence, rid themselves of enslaving or colonising ideas and put in place liberated practices. ${ }^{3}$

Liberated zones, however, are not limited to the physical space. While we can liberate land, our minds can remain occupied territories if we approach the colonialists' tools of knowledge production without caution. Mugo notes:

'We must never forget that dominating cultures use their institutions of superstructure to indoctrinate the oppressed and in this manner create disciples who will slavishly service their economic base. Thus, education, media, law, religion are just as important [territories] of/for occupation and liberation as land is. Many have written about the damage that mental enslavement can cause among the dominated'. ${ }^{4}$

In all fairness, Mugo leaves us with the following questions: 'Are our minds liberated zones or occupied territories? What new paradigms and theories are we as African intellectuals coming up with that can sit at the international conference tables as viable alternatives to imperialist and Western-imposed models? 5

Sen R, 'Teaching international law in Asia: The predicated pedagogue' 24 September 2020 https://www.afronomicslaw.org/2020/09/24/teaching-international-law-in-asia-the-predicatedpedagogue/ 7 march 2021.

2 Lugard F, The dual mandate in British tropical Africa, Routledge, 2013, 5.

3 Shivji I, Reimagining Pan-Africanism: Distinguished Mwalimu Nyerere lecture series 2009-2013, Mkuki na Nyota Publishers, 2015, 184-185.

$4 \quad$ Shivji I, Reimagining Pan-Africanism, 187.

5 Shivji I, Reimagining Pan-Africanism, 187.

Vol. 6:1 (2021) p. 43 
We would have to admit that the teaching of public international law (PIL), which has the job of positioning us at such tables remains Eurocentric, ${ }^{6}$ effectively reducing our law schools to factories that are releasing in the market of international lawyers products that will slavishly service Western economic interests. Indeed, PIL, as a world order, is in many ways what international lawyers (that African students have the potential to be) say it is. ${ }^{7}$

Currently, as surveys on PIL syllabi that this paper relies on reveal, African students of PIL are taught in such a way as to be international lawyers who say that PIL is simply a network of laws, doctrines, and interpretative devices that regulate relations between states in areas such as human rights, armed conflicts, trade, territorial boundaries, the sea, the space and diplomatic relations. ${ }^{8}$ And so, it happens that they are taught that 'what works has been around for a long time' and 'let's work with what we have'. There is no real deep critical questioning of what exists. ${ }^{9}$ For instance, they are not taught how PIL is mostly of Western European identity, pretending to operate in a world without different cultural traditions. ${ }^{10}$ Yet, Article 13 of the International Covenant on Economic, Social and Cultural Rights (ICESCR) requires that, for education to be acceptable, it must also be culturally appropriate. ${ }^{11}$ With Africa's contact with the state-system, which is contemporary PIL, Ali Mazrui empirically observed that Africa became an amalgam of mainly European westernisation, Islamic and African cultural traditions. ${ }^{12}$ Not appreciating these traditions in the teaching of PIL in our law schools make of it culturally inappropriate-a clear violation of Article 13 of the ICESCR.

\footnotetext{
The surveys done on PIL syllabi demonstrate this. For now, it may perhaps help the reader to note that JHW Verzijl, one of the historians of the discipline, has asserted powerfully and characteristically that: 'Now there is one truth that is not open to denial or even to doubt, namely that the actual body of [public] international law, as it stands today, not only is the product of the conscious activity of the European mind, but also has drawn its vital essence from a common source of beliefs, and in both of these aspects it is mainly of Western European origin'. See Anghie A, 'The evolution of international law: Colonial and postcolonial realities' 27(5) Third World Quarterly, 2006, 739-740.

7 Chimni BS, 'An outline of a marxist course on public international law' 17(1) Leiden Journal of International Law, 2004, 4.

8 See https://www.diakonia.se/en/IHL/The-Law/International-Law1/Principles/on 11 July 2020.

9 Babatunde F, 'Some thoughts on centering Pan-African epistemic in the teaching of public international law in African universities', 183.

10 Babatunde F, 'A critical approach to international legal education in Africa: Some pivotal considerations' reflection', 2. See also Chimni BS, 'An outline of a marxist course on public international law', 7.

11 CESCR, General Comment No. 13, The right to education, 8 December 1999.

12 Mazrui A and Mutunga W, Debating the African condition: Race, gender and culture conflict: Ali Marrui and his critics Volume One, Africa World Press, 2003, 21.
}

Vol. 6:1 (2021) p. 44 
Granted this background, I separate the rest of the paper as follows. First, I provide a conceptual framework that defines 'culturally appropriate' when it comes to Africa's contact with PIL and investigates the historical continuities that have led teachers of PIL in African law schools to a teaching that is not culturally appropriate. Second, with the help of surveys on PIL syllabi in select leading African law schools in Anglophone, Francophone and Lusophone Africa, I go on to demonstrate how the teaching of PIL in a culturally inappropriate manner is a systemic problem on the continent. Third, as a recommendation, I analyse PIL as taught in the Hut at Strathmore Law School. The Hut is an intellectual movement within Strathmore Law School that has tried to contextualise Third World Approaches to International Law (TWAIL) to Africa. The movement attempts to find solutions to problems facing Africa and African peoples in areas as diverse as human rights, religion, governance, trade, regional integration, democratisation struggles, and relations with other peoples of the world. The paper ends with concluding remarks.

\section{Conceptual Framework}

\section{i. On the meaning of 'culturally appropriate'}

Article 13 of the ICESCR is the most wide-ranging and comprehensive international human rights law provision on the right to education. It conceptualises education as an empowerment right, which is to equip people with critical tools that can help them gain control over their destinies. ${ }^{13}$ In this vein, the Article does not hesitate to require that, for education to be acceptable, its form and substance must be culturally appropriate. ${ }^{14}$

To properly delve into the discussion as to which historical continuities have led teachers of PIL in African law schools to a teaching that is not culturally appropriate, it may help to first make sense of what is meant by 'culturally appropriate' in Article 13 of the ICESCR. The whole of the ICESCR and even its Commentary on Article 13 are silent on what this amounts to. ${ }^{15}$ Additionally, the legal dimension of culture in the field of human rights has not always been defined in very clear terms, despite the fact that several international human rights treaties include references to the right to culture. ${ }^{16}$ This is not surprising

\footnotetext{
CESCR, General Comment No. 13, The right to education, 8 December 1999.

CESCR, General Comment No. 13, The right to education, 8 December 1999.

15 See CESCR, General Comment No. 13, The right to education, 8 December 1999 and see the whole of the ICESCR.

16 Odello, M, The right to take part to cultural life: General comment No. 21 of the United Nations
} 
because 'culture' is one of the most extensively defined concepts in social, political, educational and even in artistic arenas. ${ }^{17}$ If we are to agree that Mugo, relied upon somehow heavily in the introduction, is a highly qualified publicist, ${ }^{18}$ then her definition of culture can help in this regard. Her definition of culture, which encompasses all other definitions as much as possible, ${ }^{19}$ should guide us on this matter. This is if Article 38 of the ICJ Statute, which recognises the works of highly qualified publicists as a secondary source of law, ${ }^{20}$ has at all, any practical relevance. Mugo notes that

'Human beings create culture as they relate to their material environment and total reality in their capacity as producers and as agents of human development/change. They create two main genres of culture: material culture and non-material culture. [Material culture] manifests itself through tangible objects...By non-material culture we mean the production of knowledge for consumption at the intellectual and imaginative levels, which can be utilised for the creation of material culture as well'. ${ }^{21}$

Both material and non-material cultures work towards the fulfilment of basic and secondary human needs. Citing Amilcar Cabral, Mugo goes on to agree that 'there are strong, dependent and reciprocal relationships that exist between the cultural situation and the economic (and political) situation in the behaviour of human societies'. ${ }^{22}$ She provides examples to demystify this:

'.. the commercial farmer consumes a very different culture from that of the peasant farmer or the worker on his/her farm. The worker lives in a doghouse, while the farmer occupies a many-roomed bungalow. The government minister definitely consumes a very different culture from that of his/her driver. The university professor's cultural world is very far removed from that of the worker who cleans the corridors of academia - and so one could go on. Although these people may work for the same institution, live in the same country and even share a common racial origin, because their economic base is not the same, the social and cultural realities are totally different. It is that factor that defines their cultural status' ${ }^{23}$

Committee on Economic, Social and Cultural Rights, 27 Anuario Espanol de Derecho Internacional, 2011, 494. See CESCR, General Comment No. 13, The right to education, 8 December 1999 and see the whole of the ICESCR.

17 Mugo M, 'Gender, ethnicity, class and culture' in Mugo M, Writing and speaking from the beart of my mind, Africa World Press, Trenton, 2012, 144.

18 See generally Helmersen S, 'Finding the most highly qualified publicists: Lessons from the International Court of Justice' 30(2) European Journal of International Law, 2019.

19 Mugo M, 'Gender, ethnicity, class and culture', 144.

20 Article 38, Statute of ICJ.

21 Mugo M, 'Gender, ethnicity, class and culture', 144.

22 Mugo M, 'Culture and imperialism' in Mugo M, Writing and speaking from the heart of my mind, Africa World Press, Trenton, 2012, 128.

23. Mugo M, 'Culture and imperialism', 132-133.

Vol. 6:1 (2021) p. 46 
Given the relationship between one's cultural status and their economic base, it would be unanalytical, unscientific and a serious generalisation to simply speak of 'African culture' as a homogenous collective. Different Africans consume different cultures depending on the economic base associated with their class. ${ }^{24}$ Perhaps analysing the genres of culture that all the various classes in neo-colonial Africa consume would help substantiate this claim. ${ }^{25}$

For reasons of space, it is however enough for me to focus on culture when it comes to Africa's relation with PIL. PIL, as a world order, is a very class-based territory. As far as culture is concerned, there are two expressions of culture within PIL: one is of domination and the other of resistance. ${ }^{26}$ The culture of domination is associated with PIL's ruling class-European westernisation. ${ }^{27} \mathrm{JHW}$ Verzijl, one of the historians of PIL, has asserted powerfully and characteristically that:

Now there is one truth that is not open to denial or even to doubt, namely that the actual body of [public] international law, as it stands today, not only is the product of the conscious activity of the European mind, but also has drawn its vital essence from a common source of beliefs, and in both of these aspects it is mainly of Western European origin. ${ }^{28}$

Other cultural traditions have been resisting this and have in the process formed a culture of resistance, ${ }^{29}$ which is today mainly sustained by TWAIL scholars. TWAIL promotes the interests, concerns, histories and struggles that have been relegated to the margins of legal theory only because they are from the 'others' (other cultural traditions). ${ }^{30}$ With Africa's contact with the state-system, which is PIL, Ali Mazrui empirically and theoretically observed that Africa became an amalgam of mainly European westernisation, Islamic and African cultural traditions. ${ }^{31}$ Within this amalgam, European westernisation has obviously acted as the dominant culture, silencing the 'others'-Islamic and, especially, African cultural traditions. ${ }^{32}$

\footnotetext{
Mugo M, 'Culture and imperialism', 128.

Mugo M, 'Culture and imperialism', 133.

See Mazrui A, The Africans: A triple heritage, 12. See also Mugo M, 'Culture and imperialism', 133.

Mazrui A, The Africans: A triple heritage, 12.

28 Anghie A, 'The evolution of international law: Colonial and postcolonial realities' 25(5) Third World Quarterly, 2007, 739-740.

29 Mugo M, 'Culture and imperialism', 142.

30 Gathii J, 'TWAIL: A brief history of its origins, its decentralized network, and a tentative bibliography' 3(1) Trade, Law and Development, 2011, 368.

31 See generally Mazrui A, The Africans: A triple heritage.

32 Mazrui A, The Africans: A triple beritage, 12.
} 


\section{ii. Historical Continuities}

Indeed, before Islam and European westernisation set their footprints on the 'dark continent', Africans were living in almost virgin societies, going about their day-to-day lives as per the dictates of their cultural traditions. Islam was the first visitor. It brought a unique expression of culture that was peacefully pollinated with African cultural traditions via institutions such as local languages, political and social systems, agriculture, architecture, trade, religion, and education. ${ }^{33}$

If a peaceful pollination of cultures defined Africa's contact with Islam, its contact with European westernisation was marked with a neglect of Islamic and, especially, of African cultural traditions. With the mind and methods of Europe, European westernisation came as a dominant culture, bullying and, in many cases destroying, the cultures it found in place. ${ }^{34}$ Cultural dominance could lead to economic dominance given the link that exists between the cultural situation of a class and its economic base. ${ }^{35}$ There are three main institutions that the colonialists manipulated to maintain cultural and economic dominance over Africa: media, religion and education. ${ }^{36}$ I spend some time on legal education since it goes to the core of this paper. This is to help investigate the historical continuities that have led teachers of PIL to a teaching that is not culturally appropriate.

Education cannot be ideologically neutral. It services the economic base of the political system that birthed it. It therefore projects the world view of such a political system. ${ }^{37}$ In colonial Africa, it projected the world view of the ruling class: European westernisation. Tiyambe Zeleza notes colonial legal education was 'unapologetically Eurocentric, patterned on the metropolitan universities from which they drew much of their faculty and curricular. ${ }^{38}$ However, it received very little attention during European colonisation in Africa. The reason for this is, as William Twinning explained, Europeans perceived that Africans would learn law as a means to achieving a career in politics. Yet, encouraging the production of politicians was a threat to the life of the colonial enterprise. ${ }^{39}$

33 Martin BG, 'Arab migrations to East Africa in medieval times' 7(3) International Journal of African Historical Studies, 1974, 367. See also Edwale T, 'Justifications, challenges and constitutionality of the penal aspects of Shari'ah law In Nigeria' 17(1) Griffith Law Review, 2008,185.

34 Lugard F, The dual mandate in British tropical Africa, 5. See also Mugo M, 'Gender, ethnicity, class and culture', 147. See also Mugo M, 'Culture and imperialism', 133.

35 Mugo M, 'Culture and imperialism', 133-135.

36 Mugo M, 'Culture and imperialism', 133-135.

37 Mugo M, 'Culture and imperialism', 134.

38 Zeleza T, 'African studies and universities since independence: The challenges of epistemic and institutional decolonisation' 101 Transition, 114.

39 Ojwang JB, 'Legal education in Kenya' 33(1) Journal of African Law, 1989, 79.

Vol. 6:1 (2021) p. 48 
It is not surprising, therefore, that throughout Belgian Congo's colonial history, law was not offered as a course until the establishment of Lovanium University in 1954, six years to independence. The curriculum was modelled around that of Belgium's venerable Catholic University of Louvain. ${ }^{40}$ In colonial British Africa, there were practically no law schools. ${ }^{41}$ However, some of those who could have been assimilated into the European way of living could pursue legal education in England, Ireland and Scotland. ${ }^{42}$ It was not until 1961 that the British government looked into this matter keenly. This was by way of the Lord Denning Report on Legal education in Africa, which proposed the establishment of law degree programmes in the colonies. ${ }^{43}$ Portuguese colonial Africa did not also establish any law school, but it allowed for a few of those Africans who had been assimilated to be taken for studies to the universities of Coimbra, Oporto, and Lisbon as well as in other European countries. ${ }^{44}$ This was true for French Africa as well. The French, by way of the 1948 Report of the Commission for the Modernisation of Overseas Territories, agreed on the need for a policy to take more Africans to France for studies. ${ }^{45}$

Then, once upon a not-so-distant past, in the 1960s, African states rose in celebration with the utterances, from all corners of the continent, of 'freedom', of 'independence', of 'sovereignty'. They proclaimed: out of colonialism! This was once upon a not-so-distant past. ${ }^{46}$ Immense success was indeed amassed in having legal education available for the new citizens; many law schools were created in Belgian Congo, and British, French, and Portuguese colonial Africa. ${ }^{47}$

40 Fall B, 'Education in the Democratic Republic of Congo' 30(3) The Journal of Negro Education, 1961, 272. See also Bentrovato D and Nieuwenhuyse K, "Confronting "dark" colonial pasts: A historical analysis of practices of representation in Belgian and Congolese schools, 1945-2015' 56(3) International Journal of the History of Legal Education, 2020, 296.

41 Elias T, 'Nigeria: Legal education in Nigeria' 6(2) Journal of African Law, 1962, 117. It is, however, worth noting that the situation was different in South Africa because of Apartheid. Legal education the University of Cape Town started offering legal education in 1859 and this started expanding to other regions of the country, slowly but constantly. See Greenbaum L, 'Legal education in South Africa: Harmonising the aspirations of constitutionalism with our educational legacy' 60(2) New York Law School Law Review, 2016, 464.

42 See Ojwang JB, 'Legal education in Kenya' 79 and Elias T, 'Nigeria: Legal education in Nigeria', 125.

43 Ojwang JB, 'Legal education in Kenya', 79.

44 Duffy J, 'Portuguese Africa (Angola and Mozambique): Some crucial problems and the role of education in their resolution' 30(3) The Journal of the Negro Education, 1961, 295-298.

45 White B, 'Talk about school: Education and the colonial project in French and British Africa, (18601960)' 32(1) Comparative Education, 1996, 12.

46 Nayar J, 'Thinking being-otherwise: Returning the anti-colonial to philosophy', 1.

47 See Zeleza T, 'African studies and universities since independence: The challenges of epistemic and institutional decolonisation', 112. See also Mamdani M, Citizen and subject, 288. See also Mamdani M, 'Between the public intellectual and the scholar', 71. 
However, post-colonial African leaders failed to undertake systemic reforms of the knowledge that was at play. ${ }^{48}$

This was not more explicit in any other domain than that of the teaching of PIL which, as I will demonstrate shortly, continued to vehiculate the culture of the ruling class (European westernisation) that inheres PIL as a world order. From colonial times to the 1970s, the teaching of PIL in African law schools was mainly the dominion of European and American law teachers who were teaching the discipline with 'the mind and methods of Europe'. ${ }^{49}$ They were obviously not motivated to liberate this zone or free this space, as some would say, to make it appreciate the amalgam of cultures that forms Africa; these are African cultural traditions, Islam and European westernisation and how these have formed themselves into expressions of a culture of domination and a culture of resistance..$^{50}$

Those African teachers of PIL whom these European law teachers mentored or who were and continue to be taken for further studies within European categories of thought have perpetuated this Eurocentric way of the teaching of PIL. ${ }^{51}$ This has been done in the fashion of a Kasuku. The Kasuku story goes as follows:

'Once upon all times, there has always lived a bird known as Kasuku or parrot. The creature is at once fascinating and pathetic. $\mathrm{S} / \mathrm{he}$ is intriguing and fascinating because she excels in imitative skills - always able to produce the speaker's word, using the originator's exact pronunciation and even tone. Imitation and reproduction, or to use academic language, plagiarism, are perfected through sessions of attentive listening and repeating. However, the creature is also pathetic in the sense that $\mathrm{s} / \mathrm{he}$ can never become the owner of the source of the word. Thus, we can only call her/him a fascinating mimic, but never an intellectual thinker. The point is simple: serious intellectuals must transcend mindless repetition, mimicry and plagiarism. In this regard, forgive me if I observe that colonial and neocolonial educational systems have trained too many

48 The University of Dar-es-salaam can be an exception mainly because of the leadership of Julius Nyerere. Mazrui A, The Africans: A triple heritage, 1986, 11. See also generally See Shivji I, Reimagining pan-Africanism: Distinguished Mwalimu Nyerere lecture series 2009-2013, Mkuki na Nyota Publishers, 2015. See Zeleza T, 'African studies and universities since independence: The challenges of epistemic and institutional decolonisation', 112. See again Mamdani M, Citizen and subject, 288. See also Mamdani $\mathrm{M}$, 'Between the public intellectual and the scholar', 71.

49 Babatunde F, 'Some thoughts on centering Pan-African epistemic in the teaching of public international law in African universities', 182. See Mazrui A, The Africans: A triple beritage, 12. See also Mazrui A, 'The Re-invention of Africa', 76.

$50 \quad$ See Shivji I, Reimagining Pan-Africanism, 164-197.

51 Babatunde F, 'Some thoughts on centering Pan-African epistemic in the teaching of public international law in African universities', 182. See also Babatunde F, 'A critical approach to international legal education in Africa', 1.

Vol. 6:1 (2021) p. 50 
intellectual thieves, other areas of thievery aside. These are the types that Vadiadhar

Naipaul needed to viciously satirise in his fictional work, Mimic Men"52

Singing in the context of this mindless repetition, mimicry and plagiarism, socially self-conscious musician, Fela Anikulapo-Kuti, chronicled 'Teacher, don't teach me nonsense. 53 Another, Damini Ebunoluwa Ogulu (Burna Boy), makes these issues explicit in his 'The Monsters You Made'. Part of the song goes as follows:

'I bet they thought it was cool

Probably thought we was fools

When we would break all the rules

And skip them classes in school

Because the teacher dem teaching

What the white man dem teaching

Dem European teachings

In my African school'54

While today an African teacher teaches PIL in an African law school and to an African student, the knowledge at play is fundamentally racialised. We need to be taught from a consciousness of race. Critical Race Theory scholars, for instance, acknowledge that de jure progress in abolishing racist laws at independence should not be mistaken with de facto progress in abolishing racism. ${ }^{55}$ For these scholars, having an African teacher teaching PIL, in an African school and to an African student should not be taken as proof of the eradication of the racism that inheres the discipline. ${ }^{56}$ 'Racism is not fixed, immutable and constant across time and space. Rather, it fluctuates. It assumes different forms in different historical moments' ${ }^{57}$ In this vein, Ngugi wa Thiong'o asks:

'What should we do with the inherited colonial education system and the consciousness it necessarily inculcated in the African mind? What directions should an education system take in an Africa wishing to break with neo-colonialism? How does it want the "New Africans" to view themselves and their universe and from what base, Afrocentric

52 Mugo M, 'Burying the Kasuku syndrome', 237.

53 Babatunde F, 'Critical pedagogy of international legal education in Africa: An exploration of Fela Anikulapo-Kuti's music' in Adeola R, Nyarko M, Okeowo A and Viljoen F (eds), The art of human rights: Commingling art, human rights and the law in Africa, $1^{\text {st }}$ ed, Springer International Publishing, 2020, 7 .

54 Ebunoluwa O, 'The monsters you made' https://www.youtube.com/watch?v=lRpBLAwIbeA on 28 January 2021.

55 Gathii J, 'Writing race and identity in a global context: What CRT and TWAIL can learn from each other' 67 UCLA Law Review, 2020, 11.

56 Gathii J, 'Writing race and identity in a global context', 11.

57 Gathii J, 'Writing race and identity in a global context', 16.

Vol. 6:1 (2021) p. 51 
or Eurocentric? What then are the materials they should be exposed to, and in what order and perspective? Who should be interpreting that material to them, an African or non-African? If African, what kind of African? One who has internalised the colonial world outlook or one attempting to break free from the inherited slave consciousness? ${ }^{55}$

Below, with the help of surveys on PIL syllabi in select leading African law schools in Anglophone, Francophone and Lusophone Africa, I demonstrate how failing to answer wa Thiong'o's questions is a systemic problem on the continent, at least when it comes to the teaching of PIL.

\section{Surveys on PIL Syllabi in Select Leading African Law Schools}

A notable number of scholars have been filling the pages of academic journals, blogs, book chapters and books to critique the Eurocentric character of PIL as it relates to Africa. James Gathii classifies these scholars into contributionists and critical traditionalists. The contributionists attempt to demonstrate that PIL is not largely the product of the European mind. Pre-colonial Africa, they argue, made serious contributions to the shaping of PIL because of African and Islamic cultural traditions in this regard. The critical traditionalists, especially TWAIL scholars, go beyond these contributions. Theirs has been to critically bring to light the fact that there is a culture of domination within PIL, which favours European westernisation to the detriment of other peoples and their cultures. Taken together, both contributionists and critical traditionalists account for the two major expressions of culture that define Africa's relation with PIL: one of domination, which is European westernisation and the other of resistance, which is against such dominance and where African and Islamic cultural traditions lie. ${ }^{59}$

However, these major expressions of culture are yet to form the teaching of PIL in our law schools, which is largely only Eurocentric and hence, effectively falls short of Article 13 of the ICESCR. To justify this claim, I rely on surveys that cover a total of 23 PIL syllabi in leading African law schools. The focus on these schools is intentional. They spread across Belgian (Francophone), British (Anglophone), French (Francophone) and Portuguese (Lusophone) former colonies in Africa. My aim is to establish a pattern: that teaching PIL in

58 Mbembe J, 'Decolonising the university: New directions' 15(10) Arts and Humanities in Higher Education, 2016, 36.

59 See Gathii, 'Africa and the history of international law' Albany Law School, Legal Research Paper Series No 48 of 2011-2012, 1-2; Babatunde F, 'Some thoughts on centering Pan-African epistemic in the teaching of public international law in African universities', 170-179; See also Babatunde F 'A critical approach to international legal education in Africa: Some pivotal considerations' reflection'12 Third World Approaches to International Law Review, 2019, 2.

Vol. 6:1 (2021) p. 52 
a Eurocentric manner is a systemic problem that we inherited from European colonialism in Africa.

Babatunde Fagbayibo carried out the very first systematic surveys on these syllabi. His attention was on African countries that are former British colonies. In these countries, he surveyed the PIL syllabi of 13 law schools. These were the University of Namibia; the University of South Africa; the University of Pretoria (South Africa); Rhodes University (South Africa); University of the Gambia; University of Botswana; Moi University (Kenya); University of Zambia; Cavendish University (Uganda); University of Lagos (Nigeria); Baze University (Nigeria); the University of Swaziland; and University of Zimbabwe. ${ }^{60}$ To this list can be added surveys done by Mohamed Helal on PIL Syllabi University of Ghana, University of Nairobi (Kenya), and l' Université Internationale de Tunis (Tunisia) in 2017. ${ }^{61} \mathrm{I}$ also conducted additional surveys on PIL syllabi at Strathmore Law School, and 7 other African law schools spread across former Belgian, French and Portuguese colonies. ${ }^{62}$ These were at l'Université de Kinshasa (Democratic Republic of the Congo); ${ }^{63}$ l'Université Catholique de Bukavu (Democratic Republic of the Congo); ${ }^{64}$ l'Université Félix Houphouet d'Abidjan (Ivory Coast); ${ }^{65}$ l'Université Gaston Berger Saint-Louis (Senegal); ${ }^{66}$ 1'Université de Lomé (Togo); ${ }^{67}$ l'Université Kara (Togo), ${ }^{68}$ and Universidad Eduardo Mondlane (Mozambique). ${ }^{69}$

Despite slight variations in the form, these syllabi are strikingly similar in substance. I discuss these findings below as per some of the most commonly

${ }_{60}$ Babatunde F, 'Some thoughts on centering Pan-African epistemic in the teaching of public international law in African universities', 180.

61 Helal M, 'Teaching public international law: Reflections on the state of the art in an era of uncertainty' Ohio State University Moritz College of Law, Public Law and Legal Theory Working Paper Number 416, 2017, 4 -https://papers.ssrn.com/sol3/papers.cfm?abstract_id=3046633\# on 7 July 2020.

62 Mukuki A, Syllabus of the course public international law at Strathmore University Law School, 2018-2019.

63 Bubula S, Syllabus of the course public international law at the University of Kinshasa, 2018-2019, 33-40. The substance of the syllabus does not deviate from Babatunde's findings. It may also help the reader to focus on the core readings for the course.

${ }^{64}$ Cifende M, Syllabus of the course public international law at the Catholic University of Bukavu, 2016.

65 Yao P, Syllabus of the course public international law at the University of Félix Houphouet d'Abidjan, 2-4, 6-7, 32-33 and 36-38.

66 Wise J, Syllabus of the course public international law at the University of Gaston Berger de Saint Louis, 2006-2007.

67 Yawo K, Syllabus of the course public international law at the University of Lomé, 2018-2019.

68 Yawo K, Syllabus of the course public international law at the University of Kara, 1-60.

69 Matusse A, Syllabus of the course public international law at the University of Eduardo Mondlane, 2017-2018. See also interview with Celvicta M on 14 August 2020. 
covered topics in the teaching of PIL: history, sovereignty, sources, and treaties. In touching on these topics, my discussion will be mainly on where the contributionists or critical traditionalists or both are ignored.

\section{i. History}

On the syllabi under study, the topic on the history of PIL does not make any mention of Africa's contributions to the formation of PIL. ${ }^{70}$ Yet, the contributionists have demonstrated the role played by treaties, general principles and writings of publicists in precolonial Africa and other non-European societies. On the immunity doctrine, which 'protects public officials from liability, even when they break the law', ${ }^{71}$ these scholars have documented the diplomatic activities of ambassadors in African precolonial societies. They have also demonstrated that there used to be international relations among European and Asian exporters as well as Islamic jurists in precolonial Africa. ${ }^{72}$ In addition, a concept such as 'use of force' in public international law has been well captured in the Quran since time immemorial. ${ }^{73}$

The point is not to celebrate Africa's glorious past. Key scholars, such as Cheikh Anta Diop and Jeremy Leviit, have provided empirical findings to claim that 'PIL' in pre-colonial Africa being reflected in most of the contemporary PIL is not a matter of mere coincidence. ${ }^{74}$ Along these lines, Gurminder Bhambra notes that 'by bearing witness to different pasts one is not a passive observer but is able to turn from interrogating the past to initiating new dialogues about that past thus bringing into being new histories and from those new histories, new presents and new futures'. ${ }^{75}$ Other historical sites, Bhambra concludes, are

70 Babatunde F, 'Some thoughts on centering Pan-African epistemic in the teaching of public international law in African universities', 180-183; Helal M, 'Teaching public international law', 4; Yawo K, Syllabus of the course public international law at the University of Lomé, 2018-2019, 1-3, Wise J, Syllabus of the course public international law at the University of Gaston Berger de Saint Louis, 2006 - 2007; Yawo K, Syllabus of the course public international law at the University of Kara, 1-60; Mukuki A, Syllabus of the course public international law at Strathmore University Law School, 2018-2019, 1-8; Cifende M, Syllabus of the course public international law at the Catholic University of Bukavu, 2016, 2; Bubula S, Syllabus of the course public international law at the University of Kinshasa, 2018-2019. Lome page 2.

71 Schweikert J, 'Qualified immunity: A legal, practical and moral failure' 901 CATO Institute, $2020,2$.

72 Babatunde F, 'Some thoughts on centering Pan-African epistemic in the teaching of public international law in African universities', 180-183.

73 See generally Shah N, 'The use of force under Islamic law' 24(1) The European Journal of International Law, 2013.

74 See generally Cheikh AD, The African origin of civilisation: Myth or reality, New York, 1989.

75 Bhambra G, 'Postcolonial and decolonial dialogues' 17(2) Postcolonial Studies, 2014, 116-117.

Vol. 6:1 (2021) p. 54 
other forms of emancipation. ${ }^{76}$ This poses an urgent need 'to retell the story of knowledge generation as involving appropriations, epistemicides and the denial of humanity of others'. ${ }^{77}$

\section{ii. Sovereignty}

We are taught Eurocentric PIL, depicting it as an emancipatory, peaceful and progressive project. ${ }^{78}$ This is mostly clear when it comes to the topic of sovereignty. The sovereignty doctrine, as taught in our schools, deceptively portrays that all states are equal. Yet, in reality, it is this very doctrine that was used as a mechanism of exclusion to justify European colonisation in Africa. ${ }^{79}$ As ably articulated by Antony Anghie, 'cultural difference precedes and profoundly shapes the sovereignty doctrine'. This doctrine provided European states with all the powers of sovereignty while excluding others-the Africans included-who had to be civilised. ${ }^{80}$ This doctrine was therefore created to manage nations with different cultures and histories from those of the European. It was not created to maintain order and equality among them. ${ }^{81}$

Issa Shivji has also explained how the colonialists considered the African as a being that probably had a soul but no brains. He was a savage. 'He had no religion, no philosophy, [no civilisation]. His soul had to be saved and his society to be civilised'. ${ }^{82}$ 'Africa was another name for bestiality and barbarism'. ${ }^{83}$ This is ironic because Hitler, for instance, a white European, leading the Nazi regime, a white European government, was the quintessential savage. The barbaric and

76 Bhambra G, 'Postcolonial and decolonial dialogues', 117.

77 Ndlovu-Gatsheni S, 'Decoloniality as the future of Africa' 13(10) History Compass, 2015, 492.

78 Teaching and Researching International Law in Asia (TRILA) Project Report, NUS Centre for International Law, 2020, 29. See also Babatunde F, 'Some thoughts on centering Pan-African epistemic in the teaching of public international law in African universities', 181; Helal M, 'Teaching public international law', 4; Yawo K, Syllabus of the course public international law at the University of Lomé, 2018-2019, 1-3, Wise J, Syllabus of the course public international law at the University of Gaston Berger de Saint Louis, 2006-2007; Yawo K, Syllabus of the course public international law at the University of Kara, 1-60; Mukuki A, Syllabus of the course public international law at Strathmore University Law School, 2018-2019, 1-8; Cifende M, Syllabus of the course public international law at the Catholic University of Bukavu, 2016, 7-8; Bubula S, Syllabus of the course public international law at the University of Kinshasa, 2018-2019. Lome page 2 Chimni BS, 'An outline of a Marxist course on public international law', 7.

80 Anghie A, 'The evolution of international law', 742.

81 Gathii J, 'A critical appraisal of the international legal tradition of Taslim Olawale Elias' 21(2) Leiden Journal of International Law, 2008, 329.

82 Shivji I, The concept of human rights in Africa, Cambridge University Press, Cambridge, 2009, 1.

83 Weiner M, 'Decolonial sociology: W.E.B. Du Bois's foundational theoretical and methodological contributions' Wiley, 2018, 5. 
genocidal dimensions of the enslavement of Africans did not move the West to create the human rights movement. Neither did the classic colonisation of Asians, Africans, and Latin Americans by Europeans. 'It took the genocidal extermination of Jews in Europe - a white people - to start the process of the codification and universalisation of human rights norms' ${ }^{84}$

However, the African, being considered to have had no religion, no philosophy, and a soul to be saved as well as a society to be civilised, was denied sovereignty. This is how the doctrine of 'sovereignty of states' traces its origin to the Treaty of Westphalia of 1948. Yet there is evidence of political entities in the form of states (with a defined territory, a permanent population, a government and the capacity to enter into relations with other states) ${ }^{85}$ thousands of years prior to the birth of this Treaty. ${ }^{86}$ This is what has led Anghie to conclude that 'sovereignty legitimised the colonial rule'. ${ }^{87}$

We are also not taught that independence in Africa only meant the modification of the form of European or Western oppression of Africans but not of its substance. ${ }^{88}$ The creation of sovereignty of third world states, where Africa falls, is what Sundhya Pahuja has correctly termed PIL's 'puzzling containment of both a liberatory promise and an imperialising peril'. Indeed, for PIL to be termed 'universal', what was excluded (Africans for example) had to be included but within a system that favours the West. ${ }^{89}$ The establishment of the United Nations (UN), since 1945, has served as fertile land where the quiet universalisation of norms of European identity could flourish. ${ }^{90}$ International economic law (IEL) became crucial. For instance, terms under which the newly independent states could nationalise foreign entities became very controversial. ${ }^{91}$ It is in this way that being bound by the older rules of IEL became a precondition for the independence of our states. ${ }^{92}$ It is through this prism that we have to understand 'treaties entered into by African chiefs, and European companies or powers, supposedly ceding lands to these colonials. ${ }^{93}$ The end of formal political

\footnotetext{
84 Mutua M, 'Savages, victims, and saviors: The Metaphor of Human Rights' 42(1) Harvard International Law Journal, $210-211,2001$.

85 Article 1, Montevideo Convention on the Rights and Duties of States, 1934.

86 Gathii J, 'A critical appraisal of the international legal tradition of Taslim Olawale Elias', 324.

87 Gathii J, 'A critical appraisal of the international legal tradition of Taslim Olawale Elias', 347.

88 Bedjaoui, Towards a new international economic order, Holmes and Meier New York, 1979, 59-60 see also Anghie A, 'The evolution of international law', 741.

89 Pahuja S, 'The postcoloniality of international law' 46(2) Harvard International Law Journal, $2005,461$.

90 Mutua M, 'Savages, victims, and saviors', 214.

91 Anghie A, 'The evolution of international law', 748-749.

92 Anghie A, 'The evolution of international law', 748-749.

93 Gathii J, 'A critical appraisal of the international legal tradition of Taslim Olawale Elias', 323.
}

Vol. 6:1 (2021) p. 56 
colonisation in Africa was and has remained therefore and in significant ways a moment of betrayal. ${ }^{94}$

\section{iii. Sources}

The only sources that are recognised in the 23 syllabi are those listed under Article 38 of the Statute of the International Court of Justice (ICJ). These include treaties entered into between or among states, international custom as accepted by law and the works of highly qualified publicists. ${ }^{95}$

There is no consideration of any actions of the masses that may have led to a particular state's regulatory behaviour. ${ }^{96}$ Yet, such behaviour would help in the interpretation of a given treaty provision. ${ }^{97}$ Also, many a time, a norm is taken as international custom and courts' decisions as very persuasive when they emanate from the International Court of Justice (ICJ), which is situated in the Hague, and from other places in the West. It is in response to this that Gathii has spoken of the limited geography of places and ideas in PIL. What is taken as valid jurisprudence in this discipline is that which has been produced in the Hague, New York, or Geneva. ${ }^{98}$ Yet African courts for instance, especially those in East and West Africa, have been very progressive in furthering democratisation struggles on the continent and producing highly persuasive jurisprudence. A case in point is in Tanzania, the East African Court of Justice (EAC). The EAC has been innovative enough to adjudicate human rights issues without having any explicit jurisdiction over them. ${ }^{99}$ Equally innovative have been the courts of the Economic Community of Western African States (ECOWAS) in

94 Gathii J, 'A critical appraisal of the international legal tradition of Taslim Olawale Elias', 340.

95 Article 38, Statute of the ICJ. See also Babatunde F, 'Some thoughts on centering Pan-African epistemic in the teaching of public international law in African universities', 181-182; Helal M, 'Teaching public international law', 4; Yawo K, Syllabus of the course public international law at the University of Lomé, 2018-2019, 1-3, Wise J, Syllabus of the course public international law at the University of Gaston Berger de Saint Louis, 2006-2007; Yawo K, Syllabus of the course public international law at the University of Kara, 1-60; Mukuki A, Syllabus of the course public international law at Strathmore University Law School, 2018-2019, 2; Cifende M, Syllabus of the course public international law at the Catholic University of Bukavu, 2016, 90-91; Bubula S, Syllabus of the course public international law at the University of Kinshasa, 2018-2019. Lome page 20-21. Chimni BS, 'An outline of a marxist course on public international law', 7.

96 Rajagopal B, 'International law and social movements: Challenges of theorising resistance' 41(2) Columbia Journal of Transnational Law, 2003, 402.

97 See for instance the way the Vienna Convention on the Laws of Treaties (VCLT) does not provide for this in the way we are to go about the interpretation. Part III, Vienna Convention on the Laws of Treaties (1969).

98 Gathii J, 'The promise of international law: A third world view', Grotius Lecture Presented at the 2020 Virtual Annual Meeting of the American Society of International Law, June 2020, 8.

99 Gathii J, 'The promise of international law', 17. 
attempting to hold multinational corporations accountable for environmental rights violations. ${ }^{100}$ It is worth noting that the way Eurocentric PIL is structured, these corporations can only enjoy rights at the international level without any corresponding human rights obligations. ${ }^{101}$

The works of highly qualified publicists are also secondary sources of law under Article 38 of the ICJ Statute. ${ }^{102}$ However, these works amount, in many ways, to the subjectivity of a landowning white European male, which is taken as the basis of objectivity. ${ }^{103}$ No contributionist or critical traditionalist is acknowledged. Capturing this fact succinctly, Mohsen Al attar notes:

'Today, like yesterday, legal education persists in centring the European white male, an overrepresentation that translates into a suffocating outlook. Mainstream international legal history, as we portray it, furnishes a glowing example: Francisco de Vitoria was a Spanish Catholic theologian in the court of Ferdinand and Isabella; Hugo Grotius was in-house counsel for the Dutch-East India Company; Emer de Vattel, the son of a Swiss-Protestant clergyman, read Christian theology and metaphysics; John Westlake of Cornwall lectured at Cambridge and was the British delegate at the International Court of Arbitration; Lassa Oppenheim studied law in Germany before emigrating to England to take up appointments at the LSE and Cambridge; and Hersch Lauterpacht was Polish and also served at the same institutions. All were European, white, male, and paramount in developing Eurocentric international law'. ${ }^{104}$

Studying some contemporary publicists of the most widespread books of PIL such as Ian Brownlie, Malcolm Evans, Malcolm Shaw, James Crawford, and Jan Klabbers, who are even relied upon in some African schools, ${ }^{105} \mathrm{Al}$ attar was able to demonstrate that these scholars have not really deviated from the works of those listed in the quotation above. They refuse to admit that there is a culture of domination that inheres Eurocentric PIL and that has facilitated and continues to facilitate colonialism and neo-colonialism. ${ }^{106}$ Are these scholars better because 'Europeans are better, nobler, greater and more gifted? Europe

\footnotetext{
100 Gathii J, 'The promise of international law', 12.

101 Kurtz J, 'The shifting landscape of international investment law and its commentary' 106(3) The American Journal of International Law, 2012, 686.

102 Article 38, Statute of ICJ.

$103 \mathrm{Al}$ Attar M, 'Teacher don't teach me nonsense: Must international pedagogy remain Eurocentric', 3.

104 Al Attar M, 'Teacher don't teach me nonsense: Must international pedagogy remain Eurocentric', 8.

105 See for instance Mukuki A, Syllabus of the course public international law at Strathmore University Law School, 2018-2019; Babatunde F, 'Some thoughts on centering Pan-African epistemic in the teaching of public international law in African universities', 181, 182; Matusse A, Syllabus of the course public international law at the University of Eduardo Mondlane, 2017-2018. See also interview with Celvicta M on 14 August 2020.

106 Al Attar M, 'Teacher don't teach me nonsense: Must international pedagogy remain Eurocentric', 8-11.
}

Vol. 6:1 (2021) p. 58 
has never produced and never will in our day bring forth a single human soul who cannot be matched and overmatched in every line of human endeavour by Africa'. ${ }^{107}$

\section{iv. Treaties}

The treaty of treaties, the Vienna Convention on Law of treaties (VCLT), came in handy in 1969 to further Western economic interests. In Article 2, the VCLT defines a treaty as 'an international agreement concluded between states in written form and governed by international law, whether embodied in a single document or more related instruments, and whatever its particular designation'. ${ }^{108}$ From this reading, it is clear that the VCLT favours powerful participants in the treaty-making process. That states enter treaties out of their own consent is a deceptively simple point. Treaties provide the soil in which quiet coercion and undue influence flourish. Treaty-making process happens in a world of uneven resources and opportunity costs. ${ }^{109}$ There is also the question of who consents to a treaty: should it be an individual or peoples? ${ }^{110}$ Korovin and Pashukanis have proposed the following definition for a treaty: 'Every international agreement is the expression of an established social order, with a certain balance of collective interests' ${ }^{111}$ The syllabi under study do approach treaties critically. ${ }^{112}$

\section{The Hut at Strathmore, Teaching of PIL and TWAIL}

As should be apparent from the preceding part of the paper, the teaching of PIL in African law schools is not culturally appropriate because it does not account for the major expressions of culture that define Africa's relation with PIL. I turn now to discussing the Hut at Strathmore Law School as a recommendation

\footnotetext{
Weiner M, 'Decolonial sociology: W.E.B. Du Bois's foundational theoretical and methodological contributions', 7 .

108 Article 2(1)(a), Vienna Convention on Law of Treaties, 1969.

109 Chimni BS, 'An outline of a Marxist course on public international law', 12-14.

110 Chimni BS, 'An outline of a Marxist course on public international law', 12-14.

111 Chimni BS, 'An outline of a Marxist course on public international law', 12-14.

112 Babatunde F, 'Some thoughts on centering Pan-African epistemic in the teaching of public international law in African universities', 180; Helal M, 'Teaching public international law', 4; Yawo K, Syllabus of the course public international law at the University of Lomé, 2018-2019, 1-3, Wise J, Syllabus of the course public international law at the University of Gaston Berger de Saint Louis, 2006-2007; Yawo K, Syllabus of the course public international law at the University of Kara, 1-60; Mukuki A, Syllabus of the course public international law at Strathmore University Law School, 2018-2019, 2; Gathii J, 'The promise of international law', 90-91; Bubula S, Syllabus of the course public international law at the University of Kinshasa, 2018-2019. Lome page 20-21.
} 
for the way forward about this problem. First, I discuss what the Hut is, then I attempt to demonstrate how PIL is taught in it and, finally, I try to establish a nexus between the Hut and TWAIL.

\section{i. $\quad$ The Hut at Strathmore}

An intellectual movement known as 'the Hut' and its members 'Hutians' has taken shape in Strathmore Law School. Each academic year, Hutians gather in the Hut on Friday evenings in Sir Thomas More Building, $3^{\text {rd }}$ floor, Heritage Boardroom, to discuss matters that are critical to the lives of Africa's peoples. Hutians are predominantly students of law, from the Strathmore University Law School LLB programme. However, and on many occasions, students of political science, business and information technology as well as lecturers of various units also gain Hutian status by simply frequenting the Hut. There are no rules of attendance.

The Hut excludes no one. ${ }^{113}$ Any Hutian can chair the discussions of the day. Such discussions are very informal but deeply thought-provoking. The aim of Hutians has never been to tackle any of them conclusively. In fact, Hutians 'agree to disagree'. The only thing that they all agree on is their theoretical framework: the Triple Heritage. ${ }^{114}$ But even then, they have argued that this conceptual framework does not really capture globalisation and all its challenges. ${ }^{115}$

Ali Mazrui advanced this conceptual framework to explain certain phenomena in post-colonial Africa. Out of academic goodwill, he produced a nine-part film available on YouTube and further elaborated in a book. ${ }^{116}$ The Triple Heritage paints Africa as a confluence of indigenous, Islamic and western cultures. ${ }^{117}$ African indigenous institutions have been at peace with Islam. ${ }^{118}$ However, with the forces of western civilisation, they have been in a perennial war. ${ }^{119}$ The war has been heightened with Africa's entry into the state system, which incorporated Africans in a world culture that is primarily Eurocentric-

\footnotetext{
113 See all the Hutians interviewed.

114 Interview with Ambani J on 15 July 2020.

115 See Hutians interviewed.

116 Mazrui A, The Africans: A triple beritage. See also for instance https://www.youtube.com/ watch?v=zyZHhMtgDzM on 22 August 2020.

117 Mazrui A and Mutunga W, Debating the African condition: Race, gender and culture conflict: Ali Mazrui and his critics Volume One, Africa World Press, 2003, 21.

118 Mazrui A, The Africans: A triple beritage, 96.

119 Mazrui A, The Africans: A triple beritage, 12.
}

Vol. 6:1 (2021) p. 60 
contemporary PIL. ${ }^{120}$ The Triple Heritage is therefore a useful lens through which to view Africa's past and present social, cultural and legal existential realities.

\section{ii. The teaching of PIL in the Hut}

With the Triple Heritage, the Hut helps analyse a range of topics. Many of these topics touch on the teaching of PIL, in one way or another. Topics touching on history, sovereignty, treaties and sources in PIL, which formed the crux of our discussion in the preceding part of this paper, have been tackled critically in the Hut. Regarding the history of PIL, the film (Triple Heritage) speaks of state formations that existed in precolonial Africa and that were governed harmoniously by way of African indigenous cultural traditions. ${ }^{121}$ It also touches on state relations that existed between African kingdoms and empires and foreigners; namely, the Arabs and European missionaries. The contacts with the Arabs, and particularly Islam, led to state formations in East and West Africa. ${ }^{122}$ Because of this, the film is critical of the Westphalian Treaty of 1648, which is taken in Eurocentric PIL as the birth of states. ${ }^{123}$ It also demonstrates how the Berlin Conference of 1885 has led to the scramble of Africa by denying Africans any sort of sovereignty over their nations. ${ }^{124}$

The film goes on to make a compelling critique of how the scramble for Africa has come with its own problems. Notably and in agreement with WEB Du Bois, it makes it clear that this scramble resulted in the continent becoming 'a vast business organisation to reap profits for European investors out of the invested capital and forced labour of Africa'. ${ }^{125}$ For instance, we have lost billions of dollars to Europe, by way of multinational corporations, in our trade relationships. ${ }^{126}$ Further, the boundaries that the scramble of Africa led to were drawn with an arbitrary, illogical and whimsical reasoning. ${ }^{127}$ There was a story told 'about somebody's aunt whose house, at the border between Nigeria and Benin, had a bedroom in one country and a kitchen in the other'. One would wonder whether this aunt would need a passport to move from her kitchen to her

\footnotetext{
Mazrui A, The Africans: A triple heritage, 13.

See https://www.youtube.com/watch?v=zyZHhMtgDzMon 21 January 2021.

122 See https://www.youtube.com/watch?v=zyZHhMtgDzM on 21 January 2021.

123 See https://www.youtube.com/watch?v=zyZHhMtgDzM on 21 January 2021.

124 See https://www.youtube.com/watch?v=zyZHhMtgDzM on 21 January 2021.

125 Weiner M, 'Decolonial sociology: W.E.B. Du Bois's foundational theoretical and methodological contributions', 9.

126 See https://www.youtube.com/watch?v=zyZHhMtgDzMon 21 January 2021.

127 See https://www.youtube.com/watch?v =zyZHhMtgDzM on 21 January 2021.
}

Vol. 6:1 (2021) p. 61 
bedroom. ${ }^{128}$ These colonial borders have also led to a rise in tensions and even terrorism in West and East Africa. Hut discussions have taken Nigeria, Sudan and Somalia as cases in point. ${ }^{129}$

Another point that we have interacted with relating to the doctrine of sovereignty is the United Kingdom's refusal to return the Chagos Islands to the African nation of Mauritius. This was done despite an ICJ order and a UN General Assembly on the same and in favour of Mauritius. This act of 'colonisation' in the twenty-first century may lead us to really wonder whether states are equal as the sovereignty doctrine claims. ${ }^{130}$

The Rwandan genocide has also led us to question, with good reason, the relevance of a world treaty such as the UN Charter. This Charter's purpose is to further peace and security in the world. However, the UN, especially its Security Council, passively watched the Rwandan peoples slaughtering each other in $1994 .{ }^{131}$ Incidental to this discussion on treaties, we have covered the Masai agreements, which, supposedly, led the Masai nation to agree to being forced into reserves where leading a dignified life was simply impossible. This has also led us to rethink the VCLT. ${ }^{132}$

In terms of sources of PIL, perhaps I may mention our discussions on the Arusha Declaration and the TANU Policy on Socialism and Self-reliance. ${ }^{133}$ The Declaration, for example, makes a strong case that defies the non-intervention rule in international law. The non-intervention rule bars outside nations from interfering with the internal affairs of a nation. However, this declaration, in support of pan-Africanist ideals, holds that a government can show support for a political party involved in a liberation struggle in any part of Africa. This declaration may be serving as a persuasive charter in support for liberation struggles on the continent as elsewhere. ${ }^{134}$

\section{iii. The Hut and TWAIL}

From the above discussion, one may infer that there is a nexus between the Hut and TWAIL. I have conducted interviews with the Hutians to substantiate

\footnotetext{
128 Shivji I, Reimagining Pan-Africanism: Distinguished Mwalimu Nyerere lecture series 2009-2013, 172.

129 See https://www.youtube.com/watch?v=zyZHhMtgDzM on 21 January 2021.

130 E-mail from Sipalla $H$ to the Hut on 26 November 2019.

131 See https://www.youtube.com/watch?v=VJAuyIRfYIM\&t=584s on 22 January 2021 and E-mail from Ambani $\mathrm{J}$ to the Hut on 7 December 2018.

132 See https://www.youtube.com/watch?v=zyZHhMtgDzM on 21 January 2021.

133 E-mail from Ambani $J$ to the Hut on 21 September 2018.

134 E-mail from Ambani J to the Hut on 21 September 2018.
}

Vol. 6:1 (2021) p. 62 
this claim. On a typical Friday evening, about 20 Hutians walk into the Hut. This makes the 32 Hutians that I interviewed for this study a good sample population to understand the nexus between the Hut and TWAIL. ${ }^{135}$ I subdivided the interviewees into two groups: those who had been exposed to the teaching of international law generally and PIL specifically and those who had not. ${ }^{136}$

These are the questions that I asked:

i) How would you describe the Hut?

ii) What are some of the skills that you have gained from Hut discussions?

iii) What do you think is the link/connection between the Hut and International Law?

iv) How has the Hut help you understand certain units that you are taught in class?

v) Where would you want to see the Hut in the next 10-20 years?

To the question how they would describe the Hut, both groups find Hut sessions Afrocentric. Afrocentricity in this context is to be understood as an opportunity to study the world and its peoples, concepts, and history from an African worldview. ${ }^{137}$ They also unanimously agreed that critical thinking is part of the many skills that the Hut has empowered them with. Critical thinking in this context is not to be understood in the general sense. It is being critical in understanding that everything exists at a moment in history. The Hut can and does help them see beyond the teaching of PIL, which is ahistorical, at least as far as Africa is concerned. ${ }^{138}$

Those who have been exposed to international law units such as PIL found TWAIL to be the connection between the Hut and international law. Here, about 55 percent mentioned TWAIL directly as that connecting factor ${ }^{139}$ and the rest did so indirectly. ${ }^{140}$ This is not surprising since there is a close resemblance

135 I conducted the interviews individually via videoconferencing apps; namely, Zoom and Skype, and in-person.

136 Mugenda $\mathrm{O}$ and Mugenda M, Research methods, Quantitative and Qualitative Approaches. ACT, Nairobi. 10, 2003.

137 Babatunde F, 'Critical pedagogy of international legal education in Africa', 18.

138 Interview with Kibira L on 16 July 2020.

139 Interview with Paranta E on 16 July 2020, interview with Mungai M on 16 July 2020, interview with Ouma P on 17 July 2020, interview with Abungu C on 16 July 2020, interview with Kiai Gachanja on 18 July 2020, interview with Ali on 26 July 2020, interview with Kibira L on 16 July 2020, interview with Malonza M on 18 July 2020, interview with Pirbhai T on 26 July 2020, and interview with Okoh C on 18 July 2020.

140 Wairimu Manyara shared that the Hut shows one how international law is not contextualised to Africa. See interview with Manyara W on 20 July 2020.Natasha Muhoza was of the view that the 
between the Triple Heritage Theory, the philosophy of the Hutians, and TWAIL.

TWAIL, as an intellectual movement, is barely 23 years old. It dates to March 1997, when a group of Harvard Law School Global South students put together a document entitled 'Third World Association of International Law: A Vision Statement ${ }^{1141}$ which was circulated at the conference 'New Approaches to Third World Legal Studies'. ${ }^{142}$ As later explained by Gathii, who was one of the drafters of this statement, 'the ideological resistance that underlies TWAIL literature is based on the insistence of the recognition of radical cultural and civilisational plurality and diversity'. ${ }^{143}$ The Hut is just about this, although with a specific focus to Africa.

The brains behind the architectural ingenuity of the Hut, John Osogo Ambani and Humphrey Sipalla, can help us grasp the similarities between the Hut and TWAIL more comprehensively. Ambani and Sipalla started building the Hut in 2017. ${ }^{144}$ Ambani, speaking on the philosophy behind the Hut, explained that he had found that the teaching of law in Africa is from the colonial era. African authors are ignored. Where they are relied upon, they convey Western categories of thought. Frameworks that are used to analyse Africa's problems are all Western. The Hut, he passionately stated, has the job of telling the African student about this. It takes them away from the idea that Africa does not have and has never had a civilisation. The Hut is founded on the Triple Heritage Theory without which, in his opinion, it is impossible to understand Africa. ${ }^{145}$

relation between the Hut and international law is the fact that the Hut brings into perspective where Africa is in the spirit of international law. See interview with Muhoza N on 19 July 2020, Martina Saronge explained that the Hut calls upon African leaders to bear in mind that, before ratifying an international legal instrument, they have to ensure that such instrument speaks to the context of the peoples of Africa. See interview Saronge M on 19 July 2020. Jean Jeptoo has explained that everything in international law has been westernised. See interview with Jeptoo J on 16 July 2020. For Faith Gathoni, the Hut has helped her internalise better the unit International trade law because the lecturer had many TWAIL notes and has helped her go beyond what is just provided in textbooks used for her various units. See interview with Gathoni F on 13 July 2020. Jane Pauline Pamba was of the view that, in the realm of international law, the Hut helps one understand that Africa is not properly catered for because it is unique and with unique problems. See interview with Pamba JP on 13 July 2020. See also Interview with Sipalla H 9 July 2020. And, see interview with Ambani J on 15 July 2020.

141 Karin M, 'Taking stock of TWAIL stories' 10(4) International Community Law Review, 2008, 357-358.

142 Karin M, 'Taking stock of TWAIL stories', 356.

143 Gathii J, 'TWAIL: A brief history of its origins, its decentralized network, and a tentative bibliography' 3(1) Trade, Law and Development, 2011, 368.

144 Interview with Paranta E on 16 July 2020.

145 Interview with Ambani J on 15 July 2020.

Vol. 6:1 (2021) p. 64 
Sipalla, speaking on the same topic, said that, from his experience, the best way to be fully westernised is to study in an African law school. He added that this has been enhanced by the textbooks used and has been taken as the 'normal path', a path that is a denial and even contempt for one's own culture to the advantage of a European one. Therefore, he concluded, the Hut provides a space to think differently. It is all about theoretical and conceptual frameworks. It is all about seeing the same phenomenon through a different lens. ${ }^{146}$

Reading the TWAIL vision statement in line with the sentiments of the architects of the Hut, we can see some close resemblance between TWAIL and the Hut. Not surprisingly, Harrison Mbori, a loyal Hutian, stated that:

'I was actually asked to join the Hut while I was already a TWAILer. So, I intended to see it as an additional avenue for TWAIL. I am not sure whether Ambani would agree, but, to me, I see the Hut as TWAIL but a bit expanded. I therefore joined already 'born again', so to speak, and I have always wanted to impact as a TWAIL 'evangelist'. ${ }^{147}$

Relatedly, Edward Ole Paranta, a pioneer Hutian, intimated that the Hut has changed the identity of Strathmore Law School. It has introduced a new lens, which destabilises what one has known as the norm for 20 years. In his interview, he said that before the Hut, the school was not doing much in terms of Third World Approaches. ${ }^{148}$

Approximately half of the Hutians interviewed were yet to be exposed to international law in their LLB programme. However, from their interviews, one would not be wrong in maintaining that the Hut has equipped them with Afrocentric tools with which to approach PIL once introduced to it. Of this sample, 87 percent explained that the Hut has had an impact on their understanding of the unit 'Constitutional Law', which was taught to them from an Afrocentric perspective, tracing the constitutional problems of Africa to invisible legacies of European colonisation in Africa. ${ }^{149}$ The description read as follows:

\footnotetext{
146 Interview with Sipalla H 9 July 2020.

147 Interview with Harrison Mbori on 18 August 2020.

148 Interview with Paranta E on 16 July 2020.

149 Interview with Odhiambo E on 16 July 2020. See Interview with Iradukunda M on 22 July 2020. See Interview with Nyaga S on 26 July 2020. See Interview with Gichana R on July 2020. See Interview with Waweru K on 26 July 2020. See Interview with Maina T on 26 July 2020. See Interview with Pirbhai T on 26 July 2020. See Interview with Ngile T on 26 July 2020. See Interview with Okoh C on 18 July 2020. Interview with Pirbhai T on 26 July 2020. See Interview with Nur S on 18 July 2020. See Interview with Jennifer M on 26 July 2020. See Interview with Ogonda P on 18 July 2020. See also Constitutonal Law II, Course outline, facilitated by Ambani J and Mungai M, 2019-2020 academic year.
} 
'It is accurate to describe this course as one of those major and radical projects in social, political and legal re-engineering. At its core is the objective of raising consciousness among learners with a view to recruiting them as agents of the ongoing constitutional project in Kenya, and even Africa as a whole. The course begins by describing the colonial project in Africa and its unfortunate legacy that includes a badly bifurcated state. It then identifies the constitution as an instrument, which could be deployed in the transformation of a society in transition'.150

\section{Concluding Remarks}

Like any human institution, the Hut has not been immune to criticism. During my time at the Hut, some of the criticisms that have been raised include, for instance, that we racialise scholarship so that an author or artist cannot be read or listened to only because of the colour of their skin. I have discussed somewhere in part III of this paper that, historically, the geography of PIL has been limited to places and ideas of Caucasian ancestry. Even a progressive reading of the International Convention on the Elimination of All of Racial Discrimination (ICERD), one may argue, would encourage the Hut to keep racialising scholarship. The reason for this would be simple. One of the core aims of the ICERD is to undo historical racial subordination. ${ }^{151}$ Hence, racialising scholarship is a race-conscious remedy since, in PIL classrooms, all we have been historically exposed to is Eurocentric epistemologies. ${ }^{152}$

There is, however, another fair and a two-pronged critique of the Hut that the same critics have advanced. That it is hard to see the impact of the Hut since it has approximately 20 Hutians in every session. Further, it is limited to Strathmore Law School. At best, this critique goes, the Hut remains a small circle of people who tell each other what they want to hear. ${ }^{153}$ Indeed, though this comes out as a very harsh critique, it carries a lot of wisdom. Even almost all Hutians interviewed for this paper have maintained that the Hut ends in Strathmore, the thought-provoking ideas that we generate in it seem to die along the way as 'they are not out there'. They have proposed that the Hut should go national, regional and even continental and that it should have publications on a recurring basis. A starting point for this may perhaps be to responsibly implant the Hut in other

\footnotetext{
150 Constitutonal Law II, Course outline, facilitated by Ambani J and Mungai M, 2019-2020 academic year.

151 Gathii J, 'Writing race and identity in a global context', 16-18.

152 Gathii J, 'Writing race and identity in a global context', 16-18.

153 The interviewee has chosen to remain anonymous.
}

Vol. 6:1 (2021) p. 66 
African law schools. It operates at no monetary cost. ${ }^{154}$

Perhaps, to address the low-turnout of students in Hut, as Hutians, we should be warning our fellow law students about the wealth of knowledge they may miss because of not attending the Hut sessions. ${ }^{155}$ We should warn them that they run the risk of being known as coconuts in the Ndlovu-Gatshenian parlance. One could hear Ndlovu Gatsheni saying that African students of PIL are part of those Africans known as coconuts. Inside, they are white; outside, they are black. Physically, they are located in Africa; epistemologically, they are located in Europe. Their reading and understanding of Africa is from a Eurocentric perspective. $^{156}$

There is a further point to consider. One may wonder: why should we go the Hut-way? Why not simply introduce directly the works of the contributionists and the critical traditionalists in actual PIL classrooms rather than coming up with a forum such as the Hut? There is a very small body of scholarship that tries to address this. Three trends can be discerned from it. The first seems to leave the task of decolonising the teaching of PIL to the African Union (AU), mainly under the auspices of the AU Commission on International Law (AUCIL). Pushing for this trend are Olabisi Akinkugbe, Helal and Babatunde. ${ }^{157}$

Of the three, Babatunde makes a grand proposition, which he has coined 'critical integrative approach to curriculum reform'. ${ }^{158}$ This approach calls upon African law schools to make good use of the works of contributionists and critical traditionalists or sources of information such as Bob Marley's and Fela Kuti's music, ${ }^{159}$ as well as plays, poems, novels, films, people well versed with traditional knowledge systems, ${ }^{160}$ and critical perspectives. He explained in detail how his approach would be adopted in African law schools. But, aware of the

\footnotetext{
154 See all the interviewees.

155 See Interview with Kibira L on 16 July 2020.

156 Ndlovu-Gatsheni S, Empire, global coloniality and Africa's subjectivity, 178.

157 Olabisi A, 'The African union commission on international law proposed African institute of law: Where do we go from here?', AfricLaw: Advancing the Rule and Role of Law in Africa, 21 May 2012 https://africlaw.com/category/contributors/olabisi-delebayo-akinkugbe/ on 11 July 2020. See generally Helal M, 'Teaching public international law'.

158 See generally Babatunde F, 'Some thoughts on centering pan-African epistemic in the teaching of public international law in African universities'.

159 Babatunde F, 'The music of Fela Kuti, teaching African law and the fight against international corruption', Quartz Africa, 15 May 2018 https://qz.com/africa/1267676/the-music-of-fela-kutiteaching-african-law-and-the-fight-against-international-corruption/ on 11 July 2020.

160 Babatunde F, 'Esther Mahlangu's belated recognition, and the struggle to decolonize knowledge systems', Daily Maverick, https://www-dailymaverick-co-za.cdn.ampproject.org/c/s/www. dailymaverick.co.za/opinionista/2018-04-29-esther-mahlangus-belated-recognition-and-thestruggle-to-decolonise-knowledge-systems/amp/ on 11 July 2020.
} 
financial and human resource constraints in most African law schools towards promoting a decolonial project of this caliber, and of the fact that private donors and autocratic regimes may not see this as a priority, ${ }^{161}$ Babatunde let the implementation of his approach stem from the AU, specifically through the AUCIL, ${ }^{162}$ the AU Agenda 2063 and the Pan-African Quality Assurance and Accreditation Framework (PAQAF), which is pegged on Agenda 2063. ${ }^{163}$ The AU has faltered in this regard.

The second identifiable trend is the introduction of single semester-long courses on precolonial contributions and critical perspectives to PIL. Mohsen al Attar and Vernon Tava are the brains behind this trend. Writing before Babatunde and aware of the improbability to reform fundamentally the Eurocentric teaching PIL because of institutional inertia, they have called upon motivated scholars to introduce reforms from the periphery under the guise of academic freedom. ${ }^{164}$ Leading by example, Al Attar devised a semester-long course 'From Colonialism to Globalisation: How International Law Made a Third World', ironically, at the faculty of law of the University of Auckland in New Zealand, a First World country. ${ }^{165}$ The course was divided into 3 sections. In the first section, competing conceptions of legal education were covered and questions on whether legal education should be uniform were posed. ${ }^{166}$ In the second section, students were exposed to the works of contributionists and critical traditionalists, mainly TWAILers. In the third section, there was a move from the abstract to the tangible and from the theoretical to the pragmatic. Here, specific case studies were taken every week, ranging from human rights, through intellectual property rights and the law of force, to trade; all done from a Third World perspective. ${ }^{167}$ While introducing a TWAIL project like this in a New Zealand law school could not have perhaps faced serious practical drawbacks, the same may not be well implemented in Africa because, as we learned from Babatunde.

The third identifiable trend in scholarship is to be found at the South Asian University (SAU), which is an international university, established by the South

161 Babatunde F, 'Some thoughts on centering pan-African epistemic in the teaching of public international law in African universities', 184-185.

162 Babatunde F, 'A critical approach to international legal education in Africa', 6.

163 Babatunde F, 'Some thoughts on centering pan-African epistemic in the teaching of public international law in African universities', 173.

$164 \mathrm{Al}$ Attar M and Tava V, 'TWAIL pedagogy', 9-10 (emphasis mine).

165 Kenton W, 'First world' Investopedia, 13 September 2019 https:/ /www.investopedia.com/terms/f/ first-world.asp\#: :text=First $\% 2$ Dworld $\% 20$ countries $\% 20$ tend $\% 20$ to,Japan $\% 2 \mathrm{C} \% 20$ and $\% 20$ Western\%20European\%20countries. on 22 August 2020.

166 Al Attar M and Tava V, 'TWAIL pedagogy', 26.

$167 \mathrm{Al}$ Attar M and Tava V, 'TWAIL pedagogy', 29-30.

Vol. 6:1 (2021) p. 68 
Asian Association for Regional Cooperation (SAARC). SAU teaches PIL just as $\mathrm{Al}$ attar has done in Auckland; however, with the only difference being that SAU confines that within an LLM programme. ${ }^{168}$

Building on the work of $\mathrm{Al}$ Attar and Tava, specifically carrying out reforms from the periphery under the guise of academic freedom, this paper has recommended the Hut as another possible way forward, which runs at no cost. My claim is not that the Hut should be the only way forward. It is simply another way forward. ${ }^{169}$ Decolonising initiatives are not exclusive. Consequently, it would be counterproductive to look for a single teaching method. ${ }^{170}$

When all is said and done, unless we change the character of our law schools that continue to exist on the continent as factories for the production and reproduction of coconuts, we will always fall short of Article 13 of the ICESCR. 'There is something profoundly wrong when syllabi designed to meet the needs of colonialism continue well into the [postcolonial] era'. ${ }^{171}$

\footnotetext{
168 See https://www.afronomicslaw.org/2020/09/18/south-asian-university-towards-a-south-asianapproach-to-international-law-part-i/

169 Mohsen al Attar and Vernon Tava, 'TWAIL pedagogy: legal education for emancipation', 9-10.

170 Mohsen al Attar and Vernon Tava, 'TWAIL pedagogy: legal education for emancipation', 9-10.

171 Mbembe A, 'Decolonising knowledge and the question of the archive'.
}

Vol. 6:1 (2021) p. 69 